\title{
Pendampingan Bantuan Hukum Berdasarkan Undang-Undang Nomor 16 Tahun 2011 Tentang Bantuan Hukum
}

\author{
Oleh : \\ Zainuri $^{1)}$, Dian Novita ${ }^{2)}$, \\ Fakultas Hukum, Prodi Hukum, Universitas Wiraraja ${ }^{1}$, Fakultas Hukum, Prodi Hukum, \\ Universitas Wiraraja ${ }^{2)}$ \\ E-mail: zainuri.fh@wiraraja.ac.id ${ }^{1)}$ dian.fh@wiraraja.ac.id ${ }^{21}$,
}

\begin{abstract}
Abstrak
Dibentuknya Undang-Undang tentang Bantuan Hukum ini menjadi dasar bagi negara untuk menjamin warga negara khususnya bagi orang atau kelompok orang miskin untuk mendapatkan akses keadilan dan kesamaan di hadapan hukum. Oleh karena itu, tanggung jawab negara harus diimplementasikan melalui pembentukan Undang-Undang tentang Bantuan Hukum. Undang-Undang Republik Indonesia Nomor 16 tahun 2011 tentang Bantuan Hukum. Dengan adanya UU tentang bantuan hukum bagi masyarakat tersebut bagi masyarakat tentunya belum banyak yang tahu termasuk juga masyarakat yang ada di Desa Bluto kecamatan Bluto Kabupaten Sumenep.
\end{abstract}

Kata Kunci: Pendampingan dan Bantuan Hukum

\section{Pendahuluan}

Undang-Undang tentang Bantuan Hukum mengatur mengenai pengertian Bantuan Hukum, Penerima Bantuan Hukum, Pemberi Bantuan Hukum, hak dan kewajiban Penerima Bantuan Hukum, syarat dan tata cara permohonan Bantuan Hukum, pendanaan, larangan, dan ketentuan pidana. UU tentang Bantuan Hukum ada karena Hak atas Bantuan Hukum telah diterima secara universal yang dijamin dalam Kovenan Internasional tentang Hak-Hak Sipil dan Politik (International Covenant on Civil and Political Rights (ICCPR)). Pasal 16 dan Pasal 26 ICCPR menjamin semua orang berhak memperoleh perlindungan hukum serta harus dihindarkan dari segala bentuk diskriminasi. Penyelenggaraan pemberian Bantuan Hukum kepada warga negara merupakan upaya untuk memenuhi dan sekaligus sebagai implementasi negara hukum yang mengakui dan melindungi serta menjamin hak asasi warga negara 
akan kebutuhan akses terhadap keadilan (access to justice) dan kesamaan di hadapan hukum (equality before the law).

Jaminan atas hak konstitusional tersebut belum mendapatkan perhatian secara memadai, sehingga dibentuknya Undang-Undang tentang Bantuan Hukum ini menjadi dasar bagi negara untuk menjamin warga negara khususnya bagi orang atau kelompok orang miskin untuk mendapatkan akses keadilan dan kesamaan di hadapan hukum. Oleh karena itu, tanggung jawab negara harus diimplementasikan melalui pembentukan Undang-Undang tentang Bantuan Hukum. UndangUndang Republik Indonesia Nomor 16 tahun 2011 tentang Bantuan Hukum disahkan Presiden Dr. H. Susilo Bambang Yudhoyono pada tanggal 2 November 2011 di Jakarta. UndangUndang Republik Indonesia Nomor 16 tahun 2011 tentang Bantuan Hukum mulai berlaku setelah diundangkan oleh Menkumham Amir Syamsudin di Jakarta pada tanggal 2 November 2011. Undang-Undang Republik Indonesia Nomor 16 tahun 2011 tentang Bantuan Hukum ditempatkan pada Lembaran Negara Republik Indonesia Tahun 2011
Nomor 104. Penjelasan Atas UndangUndang Republik Indonesia Nomor 16 tahun 2011 tentang Bantuan Hukum ditempatkan pada Tambahan Lembaran Negara Republik Indonesia Nomor 5248.

Dengan adanya Undang-Undang tentang bantuan hukum bagi masyarakat miskin tersebut tentunnya bagi masyarakat belum banyak yang tahu termasuk juga masyarakat yang ada di Desa Bluto kecamatan Bluto Kabupaten Sumenep.

Ada beberapa permasalah yang menjadi pertimbangan tim pkm untuk mengadakan pengabdian di desa Bluto Kecamatan Bluto antara lain:

1. Kurangnya pengetahuan masyarakat setempat terhadap hakhaknya untuk mendapat bantuan hukum secara gratis.

2. Adanya anggapan masyarakat untuk mendapat bantuan hukum perlu biaya mahal.

3. Adanya lembaga baru di universitas wiraraja yaitu LBH yang perlu untuk diketahui oleh masyarakat luas. 


\section{Metode Pelaksanaan}

Berdasarkan permasalahan yang dialami oleh sebagian besar masyarakat, maka Tim berinisiiatif untuk memberikan pendampingan dan penyuluhan hukum berupa bantuan hukum secara gratis bagi masyarakat miskin untuk mendapatkan rasa keadilan , bilamana terjadi kasus-kasus baik pidana, perdata dan tata usaha negara sebagaimana diamanahkan dalam Undang-Undang Nomor 16 Tahun 2011 tentang bantuan hukum. Tahapan pelaksanaan berupa:

\section{Sosialisasi}

Sosialisasi akan segera tim lakukan jika sudah ada kepastian dari pihak LPPM Universitas Wiraraja terkait kegiatan ini dengan meninjau lokasi, sasaran atau mitra sebagai langkah awal di wilayah kegiatan.

2. Penyusunan Materi Penyuluhan Materi penyuluhan di susun berdasarkan atas keburtuhan program penerapan Pengabdian yang meliputi penyaluran dan pendampingan bantuan hukum.

3. Penyiapan sarana dan prasarana Sarana dan prasarana yang perlu dipersiapkan dalam kegiatan ini antara lain :
Materi pendampingan dan bantuan hukum, alat peraga penyuluhan, menyiapkan bahan presentasi, dan dokumen lain yang dibutuhkan sebagai dokumentasi kegiatan

\section{Hasil Dan Pembahasan}

\section{a. Hasil Kegiatan}

Pada pelaksanaan pengabdian kepada masyarakat yang dilakukan oleh Tim PKM dosen Fakultas Hukum Universitas Wiraraja menjelaskan tentang hak-hak masyarakat untuk mendapat bantuan hukum dan konsultasi hukum secara gratis. Banyaknya masyarakat yang tidak mengetahui akan adanya bantuan hukum secara gratis bagi masyarakat miskin. Banyaknya masyarakat dan aparat desa yang ikut andil dalam pelaksanaan sosialisasi dan pendampingan bantuan hukum, serta banyaknya pertanyaan pertanyaan yang diajukan oleh masyarakat terkait dengan kasus kasus hukum.

Harapan kami nantinya setelah selesainya pengabdian kepada masyarakat ini akan mendapatkan hasil yang maksimal yaitu dapat mewujudkan masyarakat yang 
dapat akses dalam bantuan hukum secara gratis. Faktor Pendorong dan Penghambat dari pembahasan tersebut kami mendapatkan beberapa masukan sehingga tim merangkumnya, seperti :

a. Banyaknya masyarakat yang belum mengerti akan hak dalam mendapat bantuan hukum secara gratis.

b. Banyaknya masyarakat yang belum mengetahui tentang adanya Undag-Undang No. 16 Tahun 2011 tentang bantuan hukum.

\section{b. Catatan Pembahasan}

c. Tabel Capaiian Kinerja Kegiatan Pengabdian Kepada Masyarakat oleh tim PKM Universitas Wiraraja di Desa Bluto Kecamatan Bluto Kabupaten Sumenep.

\begin{tabular}{|c|c|c|c|c|}
\hline \begin{tabular}{|l} 
Aspek \\
Kegiata \\
n
\end{tabular} & $\begin{array}{l}\text { Indika } \\
\text { taor } \\
\text { Capai } \\
\text { an }\end{array}$ & $\begin{array}{l}\text { Sebelu } \\
\text { m } \\
\text { Kegiata } \\
\text { n }\end{array}$ & $\begin{array}{l}\text { Sesuda } \\
\text { h } \\
\text { Kegiata } \\
\text { n }\end{array}$ & $\begin{array}{l}\text { Target } \\
\text { Capai } \\
\text { an }\end{array}$ \\
\hline $\begin{array}{l}\text { Undan } \\
\text { g- } \\
\text { Undan } \\
\text { g } \\
\text { Nomor } \\
16 \\
\text { Tahun } \\
2011 \\
\text { Tentan } \\
\text { g } \\
\text { Bantu }\end{array}$ & $\begin{array}{l}\text { Tujuan } \\
\text { di } \\
\text { berlak } \\
\text { ukann } \\
\text { ya } \\
\text { dan } \\
\text { pemah } \\
\text { aman } \\
\text { terhad } \\
\text { ap } \\
\text { undan }\end{array}$ & $\begin{array}{l}\text { Tidak } \\
\text { memah } \\
\text { ami dan } \\
\text { mengert } \\
\text { i } \\
\text { maksud } \\
\text { di } \\
\text { berlakuk } \\
\text { annya } \\
\text { undang- } \\
\text { undang }\end{array}$ & $\begin{array}{l}\text { Sebagia } \\
\mathrm{n} \text { besar } \\
\text { warga } \\
\text { mengert } \\
\mathrm{i} \text { dan } \\
\text { paham } \\
\text { tujuan } \\
\text { di ber } \\
\text { lakukan } \\
\text { nya } \\
\text { peratur }\end{array}$ & $\begin{array}{l}\text { Terlaks } \\
\text { ana } \\
\text { denga } \\
\text { n baik }\end{array}$ \\
\hline
\end{tabular}

\begin{tabular}{|c|c|c|c|c|}
\hline $\begin{array}{l}\text { an } \\
\text { Huku } \\
\text { m }\end{array}$ & $\begin{array}{l}\text { g- } \\
\text { undan } \\
\mathrm{g} \\
\text { nomor } \\
16 \\
\text { tahun } \\
2011 \\
\text { tentan } \\
\text { g } \\
\text { bantua } \\
\text { n } \\
\text { hukum }\end{array}$ & $\begin{array}{l}\text { nomor } \\
16 \\
\text { tahun } \\
2011 \\
\text { tentang } \\
\text { bantuan } \\
\text { hukum. }\end{array}$ & $\begin{array}{l}\text { an } \\
\text { tersebut }\end{array}$ & \\
\hline $\begin{array}{l}\text { Penger } \\
\text { tian } \\
\text { bantua } \\
\mathrm{n} \\
\text { hukum } \\
\text { dan } \\
\text { masya } \\
\text { rakat } \\
\text { miskin }\end{array}$ & $\begin{array}{l}\text { Menge } \\
\text { tahui } \\
\text { tentan } \\
\mathrm{g} \\
\text { bantua } \\
\mathrm{n} \\
\text { hukum } \\
\text {. }\end{array}$ & $\begin{array}{l}\text { Sebagia } \\
\mathrm{n} \text { kecil } \\
\text { dari } \\
\text { masyara } \\
\text { kat } \\
\text { belum } \\
\text { mengert } \\
\text { i } \\
\text { tentang } \\
\text { bantuan } \\
\text { hukum. }\end{array}$ & $\begin{array}{l}\text { Masyara } \\
\text { kat } \\
\text { memah } \\
\text { ami } \\
\text { tentang } \\
\text { UU } \\
\text { bantuan } \\
\text { hukum }\end{array}$ & $\begin{array}{l}\text { Dapat } \\
\text { dimanf } \\
\text { aatkan } \\
\text { oleh } \\
\text { masyar } \\
\text { akat } \\
\text { denga } \\
\text { n baik. }\end{array}$ \\
\hline $\begin{array}{l}\text { Koordi } \\
\text { nasi } \\
\text { masya } \\
\text { rakat } \\
\text { dgn } \\
\text { bebera } \\
\text { pa } \\
\text { pihak } \\
\text { yang } \\
\text { terkait } \\
\text { lemba } \\
\text { ga } \\
\text { bantua } \\
\mathrm{n} \\
\text { hukum }\end{array}$ & $\begin{array}{l}\text { Sama- } \\
\text { sama } \\
\text { menge } \\
\text { rti } \\
\text { tentan } \\
\text { g } \\
\text { bantua } \\
\text { n } \\
\text { hukum }\end{array}$ & $\begin{array}{l}\text { Masih } \\
\text { banyak } \\
\text { masyara } \\
\text { kat yang } \\
\text { sulit } \\
\text { untuk } \\
\text { mendap } \\
\text { at } \\
\text { bantuan } \\
\text { hukum } \\
\text { secara } \\
\text { gratis. }\end{array}$ & $\begin{array}{l}\text { Mengop } \\
\text { timalka } \\
\mathrm{n} \text { warga } \\
\text { masyara } \\
\text { kat } \\
\text { untuk } \\
\text { mendap } \\
\text { at } \\
\text { bantuan } \\
\text { hukum. }\end{array}$ & $\begin{array}{l}\text { Dapat } \\
\text { dilaksa } \\
\text { nakan } \\
\text { denga } \\
\text { n baik } \\
\text { oleh } \\
\text { warga }\end{array}$ \\
\hline $\begin{array}{l}\text { Partisi } \\
\text { pasi } \\
\text { Instan } \\
\text { si dan } \\
\text { perang } \\
\text { kat } \\
\text { desa } \\
\text { dalam } \\
\text { bantua } \\
\mathrm{n}\end{array}$ & $\begin{array}{l}\text { Memb } \\
\text { erikan } \\
\text { sosialis } \\
\text { asi dan } \\
\text { penda } \\
\text { mping } \\
\text { an } \\
\text { bantua } \\
\mathrm{n} \\
\text { hukum }\end{array}$ & $\begin{array}{l}\text { Kurang } \\
\text { optimal } \\
\text { nya } \\
\text { sossialis } \\
\text { asi UU } \\
\text { bantuan } \\
\text { hukum. }\end{array}$ & $\begin{array}{l}\text { Bekerja } \\
\text { sama } \\
\text { dengan } \\
\text { pihak } \\
\text { terkait } \\
\text { dalam } \\
\text { hal ini } \\
\text { pemerin } \\
\text { tah desa } \\
\text { bluto }\end{array}$ & $\begin{array}{l}\text { Respo } \\
\mathrm{n} \\
\text { positif }\end{array}$ \\
\hline
\end{tabular}




\begin{tabular}{|l|l|l|l|}
\hline hukum & $\cdot$ & & kec. \\
& & & bluto \\
& & kabupat & \\
& & en & \\
& & sumene & \\
\hline
\end{tabular}

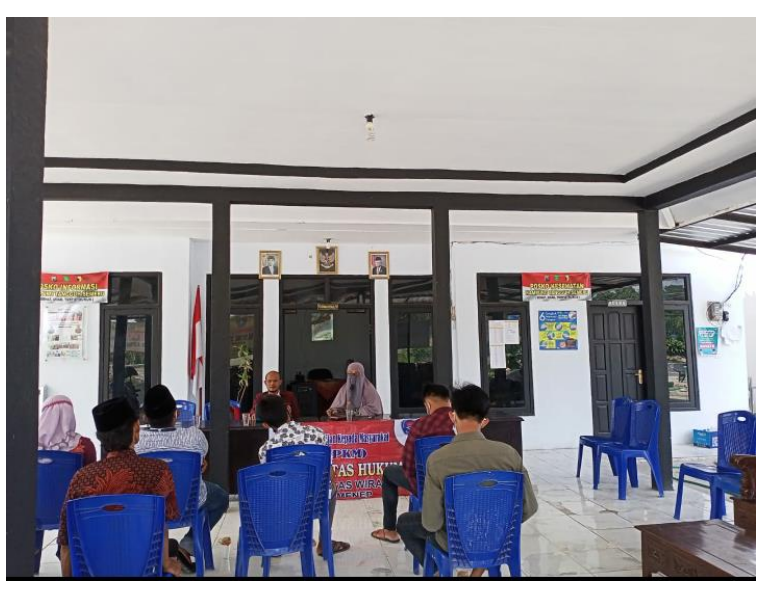

Gambar 1, pelaksanaan kegiatan sosilisasi, saat pemberian materi PKM

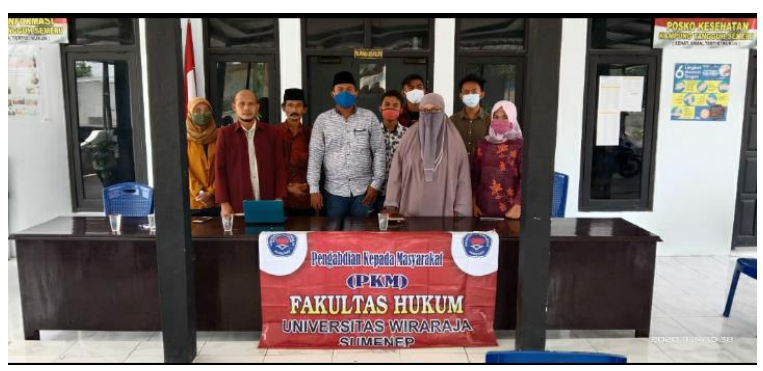

Gambar 2, pelaksanaan kegiatan sosialisasi, foto bersama dengan sebagian aparatur desa dan peserta PKM

\section{Kesimpulan}

Berdasarkan hasil sosialisasi dan pendampingan bantuan hukum terhadap masyarakat miskin, masyarakat sangat responsip terhadap Undang-Undang No. 16 Tahun 2011 tentang bantuan hukum untuk bisa menjadi payung hukum ketika terjadi kasus-kasus yang dialami oleh masyarakat miskin. Selain itu masyarakat berharap adanya tindak lanjut dari UU bantuan hukum supaya bisa di implementasikan dengan baik dengan menganding lembaga bantuan hukum yang ada.

\section{Daftar Pustaka}

Panduan Bantuan Hukum di Indonesia (Pedoman Anda Memahami Dan Menyelesaikan Masalah Hukum), YLBHI, 2014

Undang Undang Nomor 16 Tahun 2011 Tentang Bantuan Hukum 
Jurnal Abdiraja

ISSN : 2621-9379 (Online)

Volume 4, Nomor 2, September 2021 